\title{
The Introduction of Some Mushrooms as an Effective Source of Medicines in Iran Northern
}

\author{
Ebrahim Alinia-Ahandani ${ }^{1 *}$, Mohammad Fazilati ${ }^{1}$, Zahra Alizadeh $^{2}$, Ani Boghozian $^{1}$ \\ ${ }^{1}$ Biochemistry Department, Payame Noor University, Isfahan, Iran \\ ${ }^{2}$ Biology Department, Payame Noor University-Roodsar, Iran \\ *Corresponding author: Ebrahim Alinia-Ahandani, Biochemistry Department, Payame Noor University, Isfahan, Iran; E-mail: ebi.alinia@gmail.com \\ Received date: November 8, 2018; Accepted date: November 26, 2018; Published date: December 3, 2018
}

Copyright: (c) 2018 Alinia-Ahandani E, et al. This is an open-access article distributed under the terms of the Creative Commons Attribution License, which permits unrestricted use, distribution and reproduction in any medium, provided the original author and source are credited.

\begin{abstract}
Northern parts of the Iran, including Guilan and Mazandaran, are known as the best Hyrcanian forest place in the world. Most of these lands are rolling or hilly topography. There are several types of edible or medicinal mushrooms that either grows on wood (i.e., logs) or on the forest floor. My extension program in Guilan focuses on the production of shiitake (Lentinula edodes L.) mushrooms because they are becoming the best known of the exotic mushrooms, but there are several others to consider as source of medicines. In this research we overlooked mushrooms as medicinal gadgets and reviewed some varieties like Lentinula edodes L, Grifola frondosa L., Agaricus spp. L., Pleurotus spp., Morchella spp. L., Stropharia rugosa-annulata L,. Hericium spp. L., Ganoderma lucidum L. and etc. Finally we introduced some remarkable overview on some highlighted ones with point of their importance.
\end{abstract}

Keywords: Guilan; Mushroom; Exotic; Forest; Iran

\section{Introduction}

Most northern parts of the Iran, including Guilan and Mazandaran, are blessed with an abundance of forest lands. Different types of acute or chronic and infectious or non-infectious diseases at any age are always associated with suffering and economic and social burden [1]. Increasingly these lands are rolling or hilly topography. The species mixture is varied and predominantly hardwoods. Traditional forest products of saw timber and pulpwood have been harvested on these lands for more than a hundred years, and some mismanagement in the history of both provinces has resulted in large acreages of less than premium quality timber [2-4]. Another common denominator between the two provinces is large numbers of small private ownerships. There is little industrial or corporate ownership in Guilan, and Mazandaran. Both Provinces have public Hircania forest lands in their national forests - Deylaman in Lahijan and Javaher Dasht in Ramsar are two remarkable cases. Well more than three-quarters of the merchantable timber in both provinces is owned by individuals [5-7]. In Guilan, we have probably close to a 50000 owners, but the average woodland ownership is 30 acres and about $75 \%$ of those owners own even smaller woodlots, more like 10 acres. It is important then for such owners to look to their forest lands as an opportunity for some short term, non-timber forest products to give their farm economy supplemental income. Some conferences are one attempt to expose farm and forest landowners to a variety of options that they might consider for purposes as future way to produce foods $[8,9]$.

Income opportunities vary from agri-tourism or bed and breakfast, to apiculture (bees and hive products), to aquaculture (catfish, paddlefish and shrimp), to Norooz celebration like Christmas and floral greens in other usages like local Gilaki parades, to crafts materials of every description, to fence posts and fuelwood, to native fruits and nuts (e.g., pawpaw and persimmon, walnut and hazelnut), to game preserves and lease hunting, to high value timber such as paulownia and walnut, to maple syrup, to medicinal plants and mushrooms usable for culinary or medicinal purposes. This paper will focus on introduction of exotic mushrooms as medicinal plants $[10,11]$.

The aim of this study was to assess various potential of some mushrooms in Iran northern and trying more ever on discovering and description of their usage as medicinal plants branch. At first we decided to show some remarkable mushrooms as an important branch of medicinal herbs which was used and will be used as economical sources in medicine.

First of all we must tell around some newly recent introduced medicinal plants which are many other common forest floor or forestbased medicinal plants as beneficial source in medicine. For example; both black cohosh (Cimicifuga racemosa Nutt.) and blue cohosh (Caulophyllum thalictroides Michx.) are in increasing demand for the treatment of gynecological problems, and bloodroot (Sanguinaria canadensis L.) and wild ginger (Asarum canadense L.) are also marketable. Other medicinal herbs such as witch hazel (Hamamelis virginiana $L$.) and slippery elm (Ulmus rubra L.) bark are also marketable. Medicinal plant brokers are scattered all over Iran exactly northern. They will help you with details like what time of year to harvest, what part or parts of the plant they want, how to dry them correctly and how to package them for shipment $[5,8,12]$.

\section{Fungi as Medicinal Herbs}

As we know a fungus is a eukaryote group which digests food vastly and tries to absorb nutrients directly through its cell walls and structures. Most of fungi will be reproduced by spores and have a body (thallus) composed of microscopic tubular cells and structures called hyphae in scientific media. Fungi are heterotrophs and, like animals and any organisms which use foods, prepare their carbon pioneers in respiration and energy from other organisms of the world [13,14]. Also we must concentrate to some fungi which infect a living host as home, 
but dramatically kill their host cells in order to make their nutrients; these kinds of fungi named necrotrophs [15].

Fungi firstly were regarded to be basic members of the plant kingdom, a bit more advanced than bacteria kingdom. At present we know that fungi never are primitive series. In fact, recent taxonomic treatments like as the Tree of Life Project indicate that fungi and animals both belong to the group Opisthokonta. Fungi possibly won't be next kin, but they are nearly related to animals as well as plants. We also distinguish that organisms traditionally studied as "fungi" belong to three very various distinctive groups: the true fungi in Kingdom Fungi (Eumycota), the Oomycetes, and the slime molds are included [16-18].

Let's briefly regard the main groups in Kingdom Fungi-they will be explained in bigger detail later. Open most introductory mycology books and you'll find that there are four major groups (phyla) of true fungi-Ascomycota, Basidiomycota, Chytridiomycota and Zygomycota $[18,19]$. Recent learnings have provided complementary for the distinguishing of additional phyla, such as Glomeromycota, a group of fungi firstly was in Zygomycota that formed as union with the generation of most plants. A group of parasitic organisms named Microsporidia that live inside the cells of animals are also now regarded to belong in the fungal kingdom [20-22]. Hibbett et al. (2007) shared a comprehensive classification of the Kingdom Fungi Science parts, the result of collaboration among many fungal taxonomists was all and going on $[23,24]$. This kind of classification is used in the Dictionary of the Fungi [25] and other fungal references and databases in different areas. However, the best classification system will undergo additional changes as scientists use modern ways to study the fungi source. For example, Jones et al. (2011) defined the "cryptomycota," a new phylum of organisms within the Kingdom Fungi which has potential usage $[24,26]$.

Fungi are an old group of herbs-not as old as bacteria, which fossil reasons may be 3.5 billion years old age-but the most recent fungal fossils are from the Ordovician era, 460 to 455 million years old [18]. According to fossil evidence, the most recent vascular land plants didn't show until around 425 million years ago, and some scientists believe that fungi may have practical and crucial role in the colonization of land by these modern classified herbs [18,27]. Mushrooms exquisitely preserved in amber from the Late Cretaceous (94 million years ago) say us that there were mushroom-forming fungi impotently same as those that exist today when dinosaurs were roaming the planet $[22,28]$. However, the fungal fossil report is incomplete and just attends a minimum time prediction for when various groups of fungi evolved which named and assessed [29]. Molecular data recommended that fungi mostly are older than expressed by the fossil record, and may have vasted more than one billion years ago [30-32] continuous, but what is known is that at least 99,000 species of fungi have been recognized, and new-born species are described at the rate of approximately 1200 per year which must be appeared $[11,23,25]$. A conservative prediction of the general number of fungal species thought to exist is 1.5 million [14,33]. To come up with this figure, Hawksworth estimated the known numbers of plant and fungal species from countries in which both plants and fungi have been well-studied-Great Britain and Ireland, in this case-and determined there were six fungal species for every native plant species. The total number of plant species in the world is around 250,000, and if the ratio of fungi to herbs in Great Britain is typical of what happens elsewhere, there could be minimally 1.5 million species of fungi $(6 \times$ $250,000)[14,33,34]$.
If 1.5 million fungal species are reasonable prediction, the vast majority of all vast fungi are still to be named. Assuming a relatively constant rate at which new species are described, it will take more than 1100 years to catalog and describe all remaining fungi. Increasingly, most of these fungi are likely to become extinct before they are ever discovered and given daily rates of habitat and host loss in some conditions. As a case, up to $2 \%$ of tropical jungles are destroyed globally every year $[27,35]$. These habitats are vastly rich in fungal species and growth condition $[25,36]$. For example, $15-25 \%$ of fungi gathered in short studies in the tropics are new species and varieties in some places of Gilan ptovince like Lahijan and Mazandaran Province like Ramsar. Callan and Carris (2004) predicted that an 110,000 ha neotropical jungles, like as Costa Rica, could include over 81,000 various species of herb parasitic fungi-almost as many as all the known species of fungi in the world! We must pay attention that this prediction was based only on plant parasitic fungi, and did not take into account other ecological groups of fungi such as saprotrophs or something else $[4,27]$.

\section{Overlook to Mushrooms in Iran Northern}

There are several types of edible and/or medicinal mushrooms that either grow on wood (i.e., logs) or on the forest floor. My extension program in Guilan province, Northern Iran, focuses on the production of shiitake (Lentinula edodes L.) mushrooms because they are becoming the best known of the exotic mushrooms, but there are several others to consider, too [37-40].

Shiitake are brown-capped, white stemmed mushrooms native to Japan and have been cultivated in the orient for centuries especially Iran and some other parts of Middle east. Mushroom strains and spawn began to be produced in the Iran during the 1880s [24]. They grow on virtually any variety of hardwood log native to Iran although some species of trees are more productive than others, also we found some sources which lead the US as one of generation, too. Shiitake have become close to a mainstream product, as they can be found in many major supermarkets on a regular basis in some Iranian shopping package recently or some European countries. Shiitake is now primarily either imported from the orient in a dried form, or distributed from growers who are producing them on artificial substrate blocks rather than on natural hardwood logs [41,42]. There is a quality and shelf-life difference between the two, and mushrooms from natural logs are considered to be superior in all respects. Shiitake, under proper management, can be expected to flush several times during the growing season in the open. It is also possible to manage the logs under cover over the winter [32].

Grifola frondosa L., also called "hen-of-the-woods", is native to the hardwood forests of Iran and will grow both on the forest floor usually at the base of a tree - or inoculated on logs and absolutely in both places. Both mushrooms have medicinal values as well as being delicious culinary mushrooms. Maitake grows in a series of shelf or fan-like forms rather than the classic stipe (stem) and parasol (top) shape common to shiitake and button mushrooms (Agaricus spp. L.). These fans are largely brown with white markings near the edges. Medicinal effects are at least as an immune system booster, can assist with heart/blood ailments and are antiviral. Maitake usually fruit in the fall $[17,19,43]$.

Oyster mushrooms (Pleurotus spp.) are also native and come in a variety of shapes, sizes and colors. They are probably the best known "other" mushroom to buttons and Portabellas (also Agaricus spp.) and 
shiitake in the marketplace. They are commonly used, as are shiitake, in Oriental cooking. They also can be grown on logs or on other types of high cellulose substrates, and can be managed to fruit or flush on a regular basis during the growing season or year-round under cover.

Morels (Morchella spp. L.), also called "dry land fish", are also native to Iran and the United States and extremely desirable for their culinary taste as well as for their economic value. Although the life cycle of these mushrooms is known, there are a couple of details that no one seems to have quite figured out. It is known by morel hunters that the same areas yield morels frequently, if not annually, but it is very difficult to start a morel bed from scratch $[24,42]$. This is a mushroom that grows on the forest floor, and can be persuaded to grow in a sawdust mixture on the forest floor. However, all suppliers who sell kits to do this make no guarantees of success because it is such an iffy venture. Morels are common near old apple orchards and near elm trees $[44,45]$. They will start to fruit in the late spring and are so distinctive in appearance with their cone-shaped tops and their deeply pitted or sponge-like surface, it is difficult to confuse them with any other type of mushroom. The most frequently found varieties of morels are either dark brown, golden, or creamy colored on top with usually white or creamy stems $[3,46]$.

King Stropharia (Stropharia rugosa-annulata L.) is another native mushroom. These ruby red-topped, white stemmed mushrooms can grow to truly giant size (tops measured a foot or more across), but are usually harvested at a smaller size for culinary use (tops more like a few inches across). Stropharia has an unusual talent - it is considered one of the organisms that can be used for bioremediation. Of course, you would not want to use those mushrooms for eating, but if you are growing them elsewhere for food, some of the spawn you use to start your culinary bed may also be used to do a bit of environmental cleanup. Because they can grow to such a large size.

Lion's mane (Hericium spp. L.) are yet another native mushroom. This is a type of fungus that can be found growing on living trees in specialized Hyrcanian forests. It is a large $(6 "+$ across $)$ whitish or creamy mass with many small finger-like projections that point downward, thus giving it the appearance of a "mane" of hair. It is also called pompom or bearded tooth because of its appearance. It is gradually growing and probably will produce only a single mass per log or substrate in this point. It can be chopped and sauteed like other mushrooms or shredded into soups or stews as a thickener $[47,48]$.

Reishi (Ganoderma lucidum L.) is edible, but is most often used for its medicinal value. Unlike most of the other mushrooms, it forms an often shiny (shellac-look) kidney-shaped top of dark red or mahogany brown. Depending on the light and moisture conditions under which it is grown, it can also take an "antlered" form. It can grow on logs or on sterilized substrates. The Orientals consider it to be the "elixir of life" and its medicinal properties are excellent. Because of its smooth and shiny exterior, it dries easily and stores well and can be ground up for teas or other uses. Like shiitake, it requires freshly-cut living trees to colonize and will be ready to fruit in 4-6 months. It can be kept in production throughout the growing season $[49,50]$.

\section{Shiitake Mushroom Production as an Economical Case}

Shiitake spawn, the active ingredient, comes in three forms: sawdust spawn, dowel spawn, and thimble spawn. Sawdust spawn is recommended because it usually is less expensive per unit or per log inoculated, gives a more thorough and faster "spawn run", and is easy to use. The dowel spawn is the next most common and is very easy to use, as you just pound the dowels into the drilled holes with a hammer, but there is a smaller surface area to attach to the walls of the drilled holes. Thimble spawn is a recent addition from the spawn suppliers. It is pressed sawdust in the shape of a thimble and has a Styrofoam plug attached to the top, so it is considered a "wax less" type of spawn. This cuts out a whole step in the inoculation process, and so can save considerable time. For most people, especially if you plan to inoculate many logs, it will not be worth the extra handling requirements and expense.

Apparently, it is possible to inoculate freshly-cut hardwood logs at any time of the year, but it is customarily done in the winter time when the trees are dormant. Both at time of leaf fall in the late fall and the time of sap rise (maple syrup time) in the spring seem to be optimal times for the maximum amount of sugar/carbohydrates to be in the sap. That is what the fungus will be feeding on. Logs sized from 3 to 4 feet in length and from 3 to 6 inches in diameter seem to be the most manageable [35]. It is extremely important, for protection against contaminating organisms that the logs are cut from trees that were alive at the time of cutting. Ideally, plan to obtain the logs when you have all the supplies in hand and have the time to do the inoculation. The cut logs should not sit for more than two weeks before inoculating them. Brace the logs for drilling so they won't slip and drill rows of holes (at least 25-30 per log) in an overlapping pattern as you move around the log. Fill the holes with spawn and, if not using the thimble spawn, seal the inoculated holes with hot wax, sterilizing the site and holding the moist spawn inside the holes [51-53].

Just as you can't pick corn the day after you have sown the seed, you must wait for the shiitake logs to incubate for a minimum of 6 months and more likely a year or more. When the spawn has "run" throughout the log, white patches will appear on the ends of the logs. This indicates that the logs are ready to produce. During the incubation period, make sure that the logs do not dry out. If we have long spells (more than a week or ten days) without rain or snow, wet the logs down with spray from the garden hose. If the logs dry out completely, the shiitake spawn will die.

In the spring, when the logs have white patches and indicate they are ready, begin the production process. Climatic conditions should be temperatures of $65 \mathrm{~s}$ during the days and upper $35 \mathrm{~s}$ overnight. If you want controlled production, you need to divide the total number of logs you have by 9 . Take one group, immerse them in water overnight (in a stock tank, in a stream, wherever it is possible to do this), and take them out the following morning [54]. Stack them off the ground (on a pallet or on uninoculated logs) in a log cabin crib, two logs on each level with a big square opening in the middle. Stack the logs no more than 5 high on a side, 20 logs in all. Cover the stack with a 55peck bin liner plastic bag (common in the orchard industry) and brace the blind end of the bag up off the top logs [55]. Cut a small vent hole in the blind end and make sure the sides do not reach all the way to the ground. In three or four days, those logs should be covered with mushrooms. When the caps of the largest ones reach 2-3 inches in diameter, roll up the plastic and harvest them, and then roll the plastic back down for the next day. Normally, you would harvest over a twoday period but it may take three days. Mushrooms should be refrigerated as soon as possible after picking, definitely within an hour [56]. That stack of logs then rests (minus its cover) for 8 weeks before going through the cycle again. On the second week, take another ninth of your total and get them started and so forth through all your logs. Each stack should be able to be cycled through production at least twice and probably three times in a growing season [57]. 
Outlets for marketing these mushrooms continue to be supermarkets, high end ("white table cloth") restaurants, natural food stores, and farmers' markets. It is really important for you to establish what market you are going to target when you have your mushrooms. Get acquainted with the people you want to be buying your product, so that when you have mushrooms, they have a place to be sold. The global market for these mushrooms continues to expand, so they are a good investment, and a good way to take better care of your woodlands $[58,59]$.

\section{Conclusion}

We may conclude about the diverse benefits of some kinds of mushrooms towards humans. This saying inform suits mushrooms, as they have enormous medicinal food, drug and mineral values, hence they are valuable asset for the human basis in the world. In this paper all focused points were around some usages and importance of this natural gadget in Iranian usual medical life. As we know about the remarkable value of training and guarantee of culture and growth in Guilan and Mazandaran as two of the most highlighted parts in Iran. We suggest greatly investing in distinguishing of sources in mushrooms and reduce expenses in Iran northern as most rainfall parts of Iran, too.

\section{References}

1. Ahandani EA (2018) Medicinal plants and their usages in cancer. J. Pharm. Sci. Res. 10: 2-9.

2. Ahandani EA (2018) Medicinal plants with disinfectant effects. J. Pharm. Sci. Res. 10:1-1

3. Wake DB, Vredenburg VT (2008) Are we in the midst of the sixth mass extinction? A view from the world of amphibians. Proceedings of the National Academy of Sciences USA 105:11466-11473.

4. Webster J, Weber RWS (2007) Introduction to Fungi. Cambridge University Press, New York.

5. Adl SM, Simpson AG, Farmer MA, Andersen RA, Anderson OR, et al. (2005) The new higher level classification of eukaryotes with emphasis on the taxonomy of protists. J Eukaryot Microbiol. 52:399-451

6. Moore D (2001) Slayers, Saviors, Servants, and Sex. An Exposé of Kingdom Fungi. Springer, New York.

7. Rodriguez RJ, White JF Jr, Arnold AE, RS Redman (2009) Fungal endophytes: diversity and functional roles. New Phytol. 182:314-330.

8. Findlay WPK (1982) Fungi, Folklore, Fiction and Fact. The Richmond Publishing Co, Surrey, BC.

9. L Margulis, Corlis JO, Melkonian M, Chapman DJ (1989) Handbook of Protoctista. Jones and Bartlett Publishers, Boston, MA.

10. Ploetz RC (2005) Panama disease, an old nemesis rears its ugly head: Part 1 , the beginnings of the banana export trades. Online. Plant Health Progress.

11. Blackwell M, Hibbett DS, Taylor JW, Spatafora JW (2006) Research Coordination Networks: a phylogeny for kingdom Fungi (Deep Hypha). Mycologia 98:829-837.

12. Knogge W (1996) Fungal infection of plants. The Plant Cell 8:1711-1722.

13. Miadlikowska J, Kauff F, Hofstetter V, Fraker E, Grube M, et al. (2006) New insights into classification and evolution of the Lecanoromycetes (Pezizomycotina, Ascomycota) from phylogenetic analyses of three ribosomal RNA- and two protein-coding genes. Mycologia 98:1088-1103.

14. Hawskworth DL, AY Rossman (1997) Where are all the undescribed Fungi? Phytopathol 87:888-891.

15. Raper KB (1978) The penicillin saga remembered. American Society of Microbiology News 44:645-653.

16. Deacon J (2006) Fungal Biology. Fourth Edition. Blackwell Publishing Malden, MA.
17. Bromenshenk JJ, Henderson CB, Wick CH, Stanford MF, Zulich AW, et al. (2010) Iridovirus and Microsporidian Linked to Honey Bee Colony Decline. PLoS ONE 5: e13181.

18. Redecker D, Kodner R, Graham LE (2000) Glomalean fungi from the Ordovician. Science 289:1920-1921.

19. Alexopoulos CJ, Mims CW, Blackwell M, "Introductory Mycology," 4th Edition, John Wiley \& Sons Inc., New York, 1996.

20. Fry WE, Grünwald NJ (2010) Introduction to Oomycetes. The Plant Health Instructor.

21. Large EC (1940) The Advance of the Fungi. H. Holt and Company, New York.

22. Schoch CL, Shoemaker RA, Seifert KA, Hambleton S, Spatafora JW (2006) A multigene phylogeny of the Dothideomycetes using four nuclear loci. Mycologia 98:1041-1052.

23. Blackwell $\mathrm{M}$ (2011) The fungi: 1, 2, 3 .. 5.1 million species? American Journal of Botany 98:426-438.

24. Zolan ME (1995) Chromosome-length polymorphism in fungi. Microbiol Rev 59:686-698.

25. Kirk PM, Cannon PF, Minter DW, Stalpers JA (2008) Dictionary of the Fungi. 10th Edition. CAB International, Wallingford, UK.

26. Jones MDM, Forn I, Gadelha C, Egan CJ, Bass D, et al. (2011) Discovery of novel intermediate forms redefines the fungal tree of life. Nature 474:200-203.

27. Robens J, Cardwell K (2003) The costs of mycotoxin management to the USA: Management of aflatoxins in the United States. Journal of Toxicology-Toxin Reviews 22:139-152.

28. Hibbett DS, Binder M, Wang Z (2003) Another fossil agaric from Dominican amber. Mycologia 95:685-687.

29. Voyles J, Young S, Berger L, Campbell C, Voyles WF, et al. (2009) Pathogenesis of chytridiomycosis, a cause of catastrophic amphibian declines. Science 326:582-585.

30. Parfrey LW, Lahr DJG, Knoll AH, Katz LA (2011) Estimating the timing of early eukaryotic diversification with multigene molecular clocks. Proceedings of the National Academy of Sciences USA. 108:13624-13629.

31. Hughes DP, Anderson S, Hywel Jones NL, Himaman W, Billen J (2011) Behavioral mechanisms and morphological symptoms of zombie ants dying from fungal infection. BMC Ecology 11:13.

32. Zhang N, Castlebury LA, Miller AN, Huhndorf SM, Schoch C, et al (2006) An overview of the systematics of the Sordariomycetes based on a four-gene phylogeny. Mycologia 98:1076-1087.

33. Hawksworth DL (2001) The magnitude of fungal diversity: the 1.5 million species estimate revisited. Mycol Res 105:1422-1432.

34. Blehert DS, Hicks AC, Behr MJ, Meteyer CU, Berlowski-Zier BM, et al. (2009) Bat white-nose syndrome: An emerging fungal pathogen? Science. 323:227.

35. Purvis A, Hector A (2000) Getting the measure of biodiversity. Nature 405:212-219.

36. Money NP (2002) Mr. Bloomfield's Orchard. The Mysterious World of Mushrooms, Molds, and Mycologists. Oxford University Press, New York.

37. GM Mueller, Bills GF, Foster MS (2004) Biodiversity of Fungi. Inventory and Monitoring Methods. Elsevier Academic Press, San Diego, CA.

38. Money NP (2007) The Triumph of Fungi. A Rotten History. Oxford University Press, New York.

39. Duplessis S, Cuomo CA, Lin YC, Aerts A, Tisserant E (2011) Obligate biotrophy features unraveled by the genomic analysis of rust fungi. Proceedings of the National Academy of Sciences U.S.A. 108:9166-9171.

40. Nagarajan S, Singh DV (1990) Long-distance dispersion of rust pathogens. Annual Review of Phytopathology 28:139-153.

41. Letcher A, Shroom A (2007) Cultural History of the Magic Mushroom. Harper Collins, New York.

42. Suh SO, Blackwell M, Kurtzman CP, Lachance MA (2006) Phylogenetics of Saccharomycetales, the acomycete yeasts. Mycologia 98:1006-1017. 
Citation: Alinia-Ahandani E, Fazilati M, Alizadeh Z, Boghozian A (2018) The Introduction of Some Mushrooms as an Effective Source of Medicines in Iran Northern. Biol Med (Aligarh) 10: 451. doi:10.4172/0974-8369.1000451

Page 5 of 5

43. Evans HC, Elliot SL, Hughes DP (2011) Hidden diversity behind the zombie-ant fungus Ophiocordyceps unilateralis Four new species described from carpenter ants in Minas Gerais, Brazil. PLoS 6:e17024.

44. Hudler GW (1998) Magical Mushrooms, Mischievous Molds. The Remarkable Story of the Fungus Kingdom and its Impact on Human Affairs. Princeton University Press, Princeton, NJ.

45. Barron GL (1977) The Nematode-Destroying Fungi. Nature 173:500-501.

46. Stover CK, Pham XQ, Erwin AL, Mizoguchi XD, Warrener P, et al. (2000) Complete genome sequence of Pseudomonas aeruginosa PA010, an opportunistic human pathogen. Nature 406:959-964.

47. Dugan FM (2008) Fungi in the Ancient World: How Mushrooms, Mildews, Molds, and Yeast Shaped the Early Civilizations of Europe, the Mediterranean, and the Near East. APS Press-The American Phytopathological Society, St. Paul, Minnesota, U.S.A 48.

48. Shüßler A, Schwarzott D, Walker C (2001) A new fungal phylum, the Glomeromycota: phylogeny and evolution. Mycol Res 105:1413-1421.

49. Spanu PD, Abbott JC, Ameselem J, Burgis TA, Soanes DM, et al. (2010) Genome expansion and gene loss in powdery mildew fungi reveal tradeoffs in extreme parasitism. Science 330:1543-1546.

50. Kendrick B (2000) The Fifth Kingdom. Third Edition. Focus Publishing, Newburyport, MA.

51. Ploetz RC (2001) Black Sigatoka of Banana. The Plant Health Instructor.

52. Berger L, Speare R, Daszak P, Green DE, Cunningham AA, et al. (1998) H. Chytridiomycosis causes amphibian mortality associated with population declines in the rain forests of Australia and Central America. Proceedings of the National Academy of Sciences of the United States of America. 95:9031-9036.

53. Boerjan W, Ralph J, Baucher M (2003) Lignin Biosynthesis. Annual Review of Plant Biology 54:519-546.

54. White MM, TY James, K. O’Donnell, Cafaro MJ, Tanabe Y et al. (2006) Phylogeny of the Zygomycota based on nuclear ribosomal sequence data. Mycologia 98:872-874.

55. Wasson RG (1968) Soma: Divine Mushroom of Immortality. Harcourt Brace Jovanovich, New York.

56. Moore D, Robson GD, Trinci AJD (2011) 21st Century Guidebook to Fungi. Cambridge University Press, New York.

57. Kurtzman CP, J Sugiyama (2001) Ascomycetous yeasts and yeastlike fungi. Chap. 9 in: DJ McLaughlin, EG McLaughlin, PA Lemke, eds. The Mycota. Vol. VII. Systematics and Evolution Part A. Springer-Verlag, Berlin.

58. Longcore JE, Pessier AP, Nichols DK (1999) Batrachochytrium dendrobatidis gen. et sp. nov., a chytrid pathogenic to amphibians. Mycologia 91:219-227.

59. Hibbett DS, Binder M, Bischoff JF, Blackwell M, Cannon PF et al. (2007) A higher-level phylogenetic classification of the Fungi. Mycol Res 111:509-547. 